\title{
CHINA'S MANUFACTURING INDUSTRY IN AN INTERNATIONAL PERSPECTIVE: A CHINA-GERMANY COMPARISON
}

\author{
Ren Ruoen \& Bai Manying ${ }^{1}$ \\ Article received on March 25, 2002 \\ Accepted on October 10, 2002
}

\begin{abstract}
This study is the first attempt to compare China's economic performance with that of a European country following the approach of International Comparison of Output and Productivity (ICOP) developed by the Groningen University. The estimation of China's manufacturing output and value-added obtained with this method shows that China's labor productivity in 1995 was about 7 percent of the German level when small rural entreprises are excluded from the Chinese data, and was 5 percent of the German level when they are included. This is slightly higher than the result of the 1995 comparison between China and the US (Ren, Szirmai and Bai, 2002). The relative productivity performance at branch level varied considerably, from 22 percent of the German level in leather products and footwear to 3.6 per cent in paper products.
\end{abstract}

JEL Classification: E31; J24; L60.

Keywords: China; Labour Productivity; Relative Price Level.

RÉSUMÉ. Cette étude est la première tentative faite pour comparer les performances économiques de la Chine à celle d'un pays européen, en s'appuyant sur la méthodologie de comparaison internationale de production et de productivité mise au point par l'Université de Groningen. L'estimation ainsi obtenue de la production et de la valeur ajoutée manufacturière de la Chine montre qu'en 1995 la productivité du travail dans ce pays représentait environ $7 \%$ de la productivité allemande, si I'on exclut les données relatives aux petites entreprises chinoises du monde rural, et $5 \%$ quand celles-ci sont incluses. Ce résultat est légèrement plus élevé que celui obtenu pour la comparaison faite entre la Chine et les ÉtatsUnis pour 1995 ( Ren, Szirmai et Bai, 2002). Les résultats de la productivité relative au niveau des branches varient considérablement, de $22 \%$ du niveau allemand dans le cas des produits du cuir et chaussures, à 3,6\% pour le papier.

Classification JEL : E31; J24; L60.

Mots-clefs : Chine ; productivité du travail ; niveau de prix relatifs.

1. Corresponding author: ReN Ruoen, Professor, School of Economics and Management, Beihang University, and Director, Center for Competitiveness and Risk Analysis (CCRA), Beijing (ruoen8324@sina.com).

BAl Manying, Associate professor, School of Economics and Management and Research fellow, Beihang University, Center for Competitiveness and Risk Analysis, Beijing.

This research benefited from the support of the French Ministry of Economy, Finance and Industry, from the National Natural Sciences Foundation of China (79830020), and the National Soft Sciences Foundation of China (78068). 
The method of International Comparison of Output and Productivity (ICOP), developed at the University of Groningen, is regarded as being useful to measure a country's competitiveness at the industry level, and also to carry out total factor productivity comparisons across countries, such as those undertaken within the KLEMS project ${ }^{2}$.

In 1993, a research project was initiated for comparing sectoral performance in manufacturing between China and the US using this methodology. The ICOP approach requires deriving Unit Value Ratios (UVRs) from the production-side and using these UVRs to convert the value-added and production data from a local currency into a common valuation. We used this method to obtain the manufacturing GDP of both countries in a common price system, and then compared their relative labor productivity in manufacturing industry in 1985, and built time series of compared labor productivity from 1980 to 1992. This study was published in a preliminary version as a University of Groningen research memorandum (Szirmai and Ren, 1995). The revised version appeared as a chapter in The Chinese Economy (1998). The final version was published in China Economic Review (Szirmai and Ren, 2000). The findings were also incorporated in an OECD Development Centre publication (Ren, 1997).

The Chinese 1995 Industrial Census provided an opportunity to carry out new benchmark studies comparing manufacturing in China and in other countries. We thus completed a benchmark comparison between China and US manufacturing for 1995 (Ren, Szirmai and Bai, 2002).

The current paper reports the findings of a 1995 benchmark comparison between China and Germany in manufacturing using the ICOP approach, as recently refined at the University of Groningen (Timmer et al., 2001). The results of the China/Germany comparison combined with other studies allow conclusions to be drawn concerning the pattern of China's international competitiveness (productivity level, relative prices) which can be compared with the international competitiveness revealed in its foreign trade.

The paper is structured as follows. It first presents a brief discussion of the method used in this study. Then it discusses the data issues and reports the results of the comparison in fifteen branches of manufacturing for 1995. The discussion about the implication of the comparison is presented in the concluding remarks.

\section{METHOdOLOGY FOR THE 1995 BENCHMARK COMPARISON}

The ICOP methodology has been discussed in details in many papers (see Maddison and van Ark, 1988; van Ark, 1993a, 1993b; van Ark, and Pilat, 1993; Maddison, 1998; Ren, 1997; Szirmai and Ren, 2000). Timmer et al., (2001) has refined the basic approach used in the recent comparisons. Only a brief outline is presented here. More detail is to be found in APPENDIX 1.

2. The KLEMS project is an international research project aimed at measuring the contribution to economic growth of capital (K), labour (L), energy (E), intermediate materials (M), and services (S). 
The approach basically relies on binary matches of products, which are considered to be similar in the two countries. For each country, we need information at the product level on the quantities and the values of output (or sales). These data are used to calculate unit values (UVs). For each match, unit value ratios (UVRs) are calculated. The aggregation of UVRs for manufacturing is done in three steps. First, all UVRs within an industry are weighted with their gross output value. This gives us industry UVRs. Next, all industry UVRs in a branch are weighted with their gross output value. This gives a branch UVRs. Finally, all branch UVRs are weighted by branch gross output value to derive UVRs for total manufacturing.

In the binary comparison we can use either German quantity weights or Chinese quantity weights. At each level of aggregation, we therefore have two sets of UVRs. Usually, the Fisher average of these two is used to convert one country's production and value-added into the currency of the other country, to allow for comparison of real level of productivity.

\section{Data SOURCES}

\section{An overview of the data ${ }^{3}$}

\section{German data}

The basic data for Germany come from the Statistisches Bundesamt: a) Produzierendes Gewerbe. Fachserie 4. Reihe 4.3 ("Kostenstrukturdes Unternehmen im Verarbeitenden Gewerbe sowie im Bergbau und der Gewinnung von Steihen un Erden, 1995") which provides the data about the output and employment for the sample industries and branches of manufacturing, and b)"Produktion im produzierenden Gewerbe des In-und Auslands, 1995, which provides the data on the value, quantities and unit value for around 7000 products.

\section{The Chinese 1995 Industrial Census}

On the Chinese side, the basic data come from the Chinese 1995 Industrial Census. This Industrial Census includes quantity data for around 2000 products and ex-factory average prices data for about 1000 products. It also reports figures for output, value added, employment, at different industry levels.

A recent paper has provided a detailed analysis of the concepts, coverage and lack of consistency of the different time series for employment and output in China's manufacturing (Szirmai, Bai and Ren, 2001). These clarifications were made possible by using the wealth of information contained in the 1995 industrial census. These findings provided the adjusted data on output and employment used to implement the present bilateral comparison. The major data issues concern 1) the coverage of the data collected by the Census 2) the different concepts used for output and value added, and 3) employment data.

3. See also References. 


\section{Coverage of the Census data}

In the 1995 Census, production is reported according to different categories of firms. The most detailed information, corresponding to a large set of variables, is broken down by manufacturing sector only for "enterprises with independent accounting systems (IAS) at the township level and above". These include the great majority of state-owned enterprises (affiliates are excluded), urban collectives, all county and township collectives with independent accounting systems, as well as a large unspecified residual category which includes joint ventures, foreign owned enterprises, incorporated (share holding) enterprises and other enterprises. It excludes all other collectives such as village collectives and other rural collectives below township level, and all affiliates without independent accounting systems.

For enterprises which have no IAS, such as individual enterprises, private enterprises, village collectives, rural cooperatives, etc, information is scarce and incomplete, so that sectoral breakdown is not available.

The problems of coverage are getting worse over time, as China moves towards a market economy and as the ownership structure is changing. This is due to the fact that the importance of state-owned enterprises, which used to form the bulk of enterprises with IAS is declining. In 1978, independent accounting enterprises at the township level and above accounted for most of output and employment in the industrial sector, but every year this becomes less and less true. In 1985, the subset of enterprises for which detailed information was available, accounted for 87 percent of total gross output in industry. By 1995, this percentage had declined to 67 percent. Since then it has declined further. In terms of employment, the coverage declined from 68 percent in 1985 to 58 percent in 1995 (Industrial Census, 1985, 1995).

The coverage of employment in time series is even more limited than in the industrial Census. In recent Chinese statistical publications, the bulk of employment is left out of consideration, which makes it extremely difficult to study employment trends in industrial branches of manufacturing. For instance, in the published 1993-99 time series on employment, sectoral detail is only provided for 52.1 million out of a total of 147.4 million persons engaged in industry. For output, coverage is slightly better as firms with IAS tend to have higher productivity per worker than others. But these differences in coverage affect all productivity estimates.

For independent accounting enterprises at the township level and above, information is available for a wide range of variables including gross output (new concept, see below), gross output (old concept), gross value added, employment, sales tax, value added tax, total tax and several variables referring to financial dimensions (profit, wages, interest and so forth). This detailed information is not available for the enterprises below this administrative level.

Szirmai, Bai and Ren (2002) have demonstrated, that the independent accounting enterprises at the township level and above have the same coverage as the published time series for industrial output. Therefore the comparison of productivity at this level is important since it can be used to draw time series. 


\section{Definitions of output and value-added}

Since 1993, the concept of gross output has changed and now includes a few new items: value of output produced with non-purchased intermediate inputs, revenue from processing of intermediate inputs produced for others and the value of semi-finished goods and goods in process. This makes the new concept somewhat higher in value than the old one. The most important difference however, is that value added tax - introduced in 1994 - is excluded from the old concept. This makes the new concept lower in value than the old one. As the Chinese statistical practice has followed the SNA guideline, value added data excludes intermediate inputs from the manufacturing or the services industries, no matter where they come from. Annex activities were excluded from the output produced by production units and reallocated to the relevant industry. The concept of value added used in the 1995 census (and the time series) includes sales and other taxes and excludes value added taxes. By deducting sales taxes from the published figures we can get value added at factor cost, and by adding the value added taxes, we obtain value added at market prices.

\section{Employment data}

In the 1995 Census there are three concepts of employment. The first is often referred to in Chinese statistical practice as the Social Labour Force. It includes all persons engaged in industry, including persons with a second job and self employed persons, persons working in village enterprises, private enterprises and sole proprietorships. The census estimate of the social labour force in industry is 147.4 million persons.

A much more restricted concept of employment is the so-called staff and worker concept (also referred to as formal employment). This concept refers to workers with a formal employment status at township level and above, and includes part-time workers. Since 1998, the staff and worker concept has been redefined in a more restrictive sense and renamed "on-post staff and worker". This third concept excludes people who have still some kind of contractual relationship with the enterprise but are no longer actually working. The total number of staff and workers in the census in 1995 is 85 million, representing 58 per cent of the social labour force.

The labour forces working in annex activities, distinct from the major production activity, are included in employment statistics. Hence, this portion of the employment was deducted to arrive at employment figures consistent with the output figures.

\section{Data on output and employment}

In this section we present the basic data on output and employment by branch of manufacturing in Germany and in China.

As mentioned above, Chinese data derived from the 1995 Industrial Census does not provide exhaustive information. It reports detailed information for a subset of enterprises but no detailed information for the rest of enterprises. Hence, for benchmark comparison, we constructed two data sets. 
For one data set, we used the Census data for IAS enterprises at the township level and above (excluding village entreprises). This data set has a rather limited coverage but it presents detailed information on this subset of enterprises. It has two advantages: first, the data both for output and employment are taken from a single source without any adjustment; second, the coverage of this data set is consistent with that of the published time series.

For the second data set, we used the Census data for enterprises at the village level and above, with more than 1 million sales. The only categories of firms which are excluded are the individual firms, the so-called affiliated enterprises and small enterprises with less than one million sales. As the Census does not report sectoral value-added data for this extensive coverage, we calculated the value-added by sector by applying the ratio of value-added to output derived from the 1995 Input-Output table. The approach can be justified by the similarity of output structure between the 1995 Industrial Census and the 1995 Input-Output table, according to Szirmai, Bai and Ren (2001). Moreover, the employment concept corresponds to the concept of the social labour force. In constructing this data set, we thus had to make few assumptions to allow for a large coverage. The present data concerns 85 per cent of gross output, 75.5 per cent of employment, which is close to a full coverage of China's industrial sector.

So we carry out two comparisons. In these two comparisons, the German data are the same, but the Chinese data are different, corresponding to the two different levels of coverage.

The first version for Chinese data provides information about enterprises with independent accounting systems at the township level and above (TABLE 1). As discussed above the new concept of gross output is neither at factor cost, nor at market prices. For purposes of international comparison, the output figures have to be adjusted to factor cost. For these enterprises, the Chinese 1995 Industrial Census provides full details on gross output, value added, total taxes, sales and other taxes and value added taxes (and a multitude of other variables). By deducting sales taxes we arrive at factor cost concepts.

The second set of basic Chinese data (TABLE 2) refers to the broader coverage of output and employment, as it includes all enterprises at the village level and above, with annual sales of more than one million yuan. Enterprises' affiliates outside the industrial sector are excluded. Less information is available for this wider coverage: only gross output and total taxes are given. First, in order to adjust gross output figures to factor cost, we applied the ratio of sales and other taxes to total taxes observed for enterprises at the township level and above to the total tax figures for the village level and above. This gave us an estimate of sales taxes. As total taxes for the village level and above are only 9 per cent higher than in the township level and above, this is a fairly safe assumption. A similar procedure was used to estimate value added taxes. The final step was to apply value added/gross output ratios (at factor cost) from the 1995 input-output table to get estimates of gross value added for enterprises at the village level and above.

TABLE 2 provides the widest coverage available for sectoral data derived from the 1995 Industrial Census. One would indeed expect labour productivity to be lower when smaller 
Table 1 - $\quad$ Basic data on output and employment for China, 1995 (excluding the Chinese small firms*)

\begin{tabular}{|c|c|c|c|c|c|}
\hline & & $\begin{array}{c}\text { Gross Value } \\
\text { of Output } \\
\text { at factor } \\
\text { cost } \\
\text { (mill. Yuan) }\end{array}$ & $\begin{array}{l}\text { Gross Value } \\
\text { Added } \\
\text { at factor } \\
\text { cost } \\
\text { (mill. Yuan) }\end{array}$ & $\begin{array}{l}\text { Gross Value } \\
\text { Added in } \\
\text { branch as } \\
\% \text { of total }\end{array}$ & $\begin{array}{l}\text { Employment } \\
\text { (persons) }\end{array}$ \\
\hline 1. & Food and Kindred Products & 626,275 & 170,735 & 14.2 & $5,707,900$ \\
\hline 2. & Textiles Mill Products & 460,400 & 89,845 & 7.5 & $8,271,400$ \\
\hline 3. & Wearing Apparel & 147,015 & 34,729 & 2.9 & $2,618,800$ \\
\hline 4. & Leather Products and Footwear & 97,441 & 20,147 & 1.7 & $1,375,500$ \\
\hline 5. & Wood Products & 40,553 & 9,508 & 0.8 & 995,500 \\
\hline 6. & Paper Products, Printing \& Publishing & 130,399 & 29,506 & 2.5 & $2,777,000$ \\
\hline 7. & Chemicals \& Allied Products & 559,099 & 141,038 & 11.7 & $6,076,100$ \\
\hline 8. & Petroleum \& Coal Products & 202,812 & 56,133 & 4.7 & 688,200 \\
\hline 9. & Rubber and Plastic Products & 174,753 & 36,343 & 3.0 & $2,473,800$ \\
\hline 10. & Non-Metallic Mineral Products & 301,836 & 89,991 & 7.5 & $7,623,000$ \\
\hline 11. & Basic Metal Products & 503,251 & 135,533 & 11.3 & $4,571,600$ \\
\hline 12. & Fabricated Metal products & 165,072 & 38,394 & 3.2 & $2,709,100$ \\
\hline 13. & Machinery and Equipment & 412,223 & 111,916 & 9.3 & $7,405,900$ \\
\hline 14. & Transport Equipment & 330,328 & 80,512 & 6.7 & $3,704,700$ \\
\hline & Office, Accounting and Computing machinery & 35,056 & 9,209 & 0.8 & 101,100 \\
\hline 16. & Electrical Machinery and Equipment & 557,314 & 136,137 & 11.3 & $5,236,780$ \\
\hline & Other Manufacturing Products & 59,709 & 14,761 & 1.2 & $1,174,000$ \\
\hline & Total Manufacturing: & $4,803,536$ & $1,204,437$ & 100.0 & $63,510,380$ \\
\hline
\end{tabular}

* The coverage is the IAS enterprises at the township level and above.

Note: The other manufacturing product branch includes 1. Furniture manufacturing, 2. Cultural goods, sporting and athletic and recreation products, 3. Instruments, meters and other measuring equipments, 4. Cultural and office equipments. The printers, typewriter and other office equipments are included in Office, Accounting and Computing Machinery branch.

Sources: The gross value of output and value added are from p. 46-197 of the Census, while labor data are from p. 198-233 of the Census. The labor data refer to the average figures and service employment was excluded.

enterprises are included. But the difference in productivity is also due to the fact that the average value-added/output ratio for township enterprises and above (which is available in the census) is three per cent higher than the ratio derived from the 1995 Input-Output table applied in table 3 (26.7 percent versus 23.7 percent).

The data sets on China's manufacturing reported in the present comparison have slight differences compared to the similar coverage of data displayed in Szirmai, Bai, and Ren (2001, table 9 and table 10) because of two reasons. There are 17 branches in the China-Germany comparison, which follows the new classifications system while there were only 15 branches in Szirmai, Bai, and Ren (2001). The other reason is that the composition of the branch "other manufacturing" is different in the two studies.

The basic data on gross value of output, gross value added and employment for Germany are presented in TABLE 3. 
Table 2 - $\quad$ Basic data on output and employment for China, 1995 (including the Chinese small firms*)

\begin{tabular}{|c|c|c|c|c|c|}
\hline & & $\begin{array}{c}\text { Gross Value } \\
\text { of Output } \\
\text { at factor } \\
\text { cost } \\
\text { (mill. Yuan) }\end{array}$ & $\begin{array}{l}\text { Gross Value } \\
\text { Added } \\
\text { at factor } \\
\text { cost } \\
\text { (mill. Yuan) }\end{array}$ & $\begin{array}{l}\text { Gross Value } \\
\text { Added in } \\
\text { branch as } \\
\% \text { of total }\end{array}$ & $\begin{array}{c}\text { Employment } \\
\text { (persons) }\end{array}$ \\
\hline 1. & Food and Kindred Products & 731,817 & 147,746 & 11.0 & $8,060,400$ \\
\hline 2. & Textiles Mill Products & 555,730 & 93,184 & 7.0 & $10,140,000$ \\
\hline 3. & Wearing apparel & 223,257 & 50,405 & 3.8 & $4,188,700$ \\
\hline 4. & Leather products and Footwear & 140,777 & 18,750 & 1.4 & $2,365,600$ \\
\hline 5. & Wood products & 70,053 & 18,032 & 1.3 & $1,621,600$ \\
\hline 6. & Paper Products, Printing \& Publishing & 199,510 & 39,111 & 2.9 & $4,023,100$ \\
\hline 7. & Chemicals \& Allied Products & 634,149 & 123,229 & 9.2 & $7,526,800$ \\
\hline 8. & Petroleum \& Coal Products & 204,732 & 59,963 & 4.5 & 9,491 \\
\hline 9. & Rubber and Plastic products & 250,812 & 49,697 & 3.7 & $3,849,900$ \\
\hline 10. & Non-Metallic Mineral Products & 496,561 & 140,212 & 10.5 & $13,847,500$ \\
\hline 11. & Basic Metal Products & 579,001 & 123,873 & 9.2 & $5,823,400$ \\
\hline 12. & Fabricated metal products & 271,971 & 63,703 & 4.8 & $4,340,000$ \\
\hline 13. & Machinery and Equipment & 540,770 & 111,145 & 8.3 & $10,247,200$ \\
\hline 14. & Transport equipment & 369,806 & 91,532 & 6.8 & $4,793,200$ \\
\hline 15. & Office, Accounting and Computing machinery & 43,443 & 11,577 & 0.9 & 202,101 \\
\hline 16. & Electrical Machinery and Equipment & 556,036 & 128,146 & 9.6 & $6,120,300$ \\
\hline & Other manufacturing products & 274,688 & 70,919 & 5.3 & $6,669,499$ \\
\hline & Total Manufacturing: & $6,143,114$ & $1,341,225$ & 100.0 & $94,768,400$ \\
\hline
\end{tabular}

* Data on enterprises at the village level and above with more than 1 million sales.

Notes: (a) Tea making reclassified from beverages to food manufacturing; (b) Other manufacturing includes the unallocated residual for total industry. It is assumed that this residual is primarily included in manufacturing; (c) For the census total, the adjustment to factor cost and market prices was done by deducting and adding the same absolute amount of taxes as for the total industry village level and above.

The small individual enterprises pay income tax. We assume they do not pay much in the way of sales tax and VAT. We used the same proportions of value added to gross output as for total industry at the village level and above.

Data Sources:

Col. 1: Number of enterprises from Industrial Census, 1995 p. $3 \mathrm{ff}$.

Col. 2: Gross value of output (new concept), Industrial Census, 1995 p. 3 ff. The new concept is net of value added tax, but gross of sales and other taxes.

Col. 3. GVO adjusted to factor cost by deducting estimates of sales and other taxes. These taxes are estimated using the proportions of sales and other taxes to total taxes at the township level and above (Census p. 46), where more detail on taxes is provided. For page 3 only total taxes are given.

Col. 4: Value added at factor cost calculated by applying gross value added/gross output ratios from the 1995 IO table, p. $82 \mathrm{ff}$. (33 x33 use matrix) where the 1995 IO table does not have sufficient detail, it is broken down using proportions from the 1997 IO table. In some cases, value added at factor cost calculated by applying gross value added/gross output ratios from the 1995 Census data, p. 46.

Col. 7: Employment (year end from Industrial Census, 1995, p. 3 ff.), deducting service staffs.

\section{Deriving unit value ratios}

In the ICOP methodology, as a first step, unit values are derived by dividing ex-factory output values by produced quantities for each product in each country. However, because of data limitations, this approach was not applied in a satisfactory way in the 1985 China-US comparison (Szirmai and Ren, 2000). For the present study and further research agenda, we had to construct a commodity list of Chinese products with their corresponding quantities, out- 


\begin{tabular}{|c|c|c|c|c|c|}
\hline & & $\begin{array}{l}\text { Gross Value } \\
\text { of Output } \\
\text { at factor } \\
\text { cost } \\
\text { (mill. Yuan) }\end{array}$ & $\begin{array}{l}\text { Gross Value } \\
\text { Added } \\
\text { at factor } \\
\text { cost } \\
\text { (mill. Yuan) }\end{array}$ & $\begin{array}{l}\text { Gross Value } \\
\text { Added in } \\
\text { branch as } \\
\% \text { of total }\end{array}$ & $\begin{array}{l}\text { Employment } \\
\text { (persons) }\end{array}$ \\
\hline 1. & Food and Kindred Products & 250,237 & 50,906 & 7.9 & 563,935 \\
\hline 2. & Textiles Mill Products & 31,981 & 9,959 & 1.5 & 150,334 \\
\hline 3. & Wearing apparel & 22,526 & 6,123 & 1.0 & 102,923 \\
\hline 4. & Leather products and Footwear & 7,532 & 2,100 & 0.3 & 35,383 \\
\hline 5. & Wood products & 30,767 & 10,225 & 1.6 & 122,445 \\
\hline 6. & Paper Products, Printing \& Publishing & 121,195 & 44,720 & 6.9 & 539,005 \\
\hline 7. & Chemicals \& Allied Products & 225,774 & 73,211 & 11.3 & 553,305 \\
\hline 8. & Petroleum \& Coal Products & 116,157 & 3,860 & 0.6 & 24,679 \\
\hline 9. & Rubber and Plastic products & 88,811 & 32,148 & 5.0 & 365,773 \\
\hline 10. & Non-Metallic Mineral Products & 74,059 & 29,008 & 4.5 & 284,002 \\
\hline 11. & Basic Metal Products & 106,158 & 31,598 & 4.9 & 299,347 \\
\hline 12. & Fabricated metal products & 115,254 & 46,192 & 7.1 & 546,678 \\
\hline & Machinery and Equipment & 245,947 & 95,144 & 14.7 & $1,039,431$ \\
\hline 14. & Transport equipment & 313,691 & 94,068 & 14.5 & 895,895 \\
\hline & Office, Accounting and Computing machinery & 30,381 & 7,478 & 1.2 & 66,620 \\
\hline & Electrical Machinery and Equipment & 255,053 & 91,405 & 14.1 & $1,009,334$ \\
\hline & Other manufacturing products & 51,375 & 18,641 & 2.9 & 249,661 \\
\hline & Total Manufacturing: & $208,689,697$ & $64,678,664$ & 100.0 & $6,848,750$ \\
\hline
\end{tabular}

Source: Produzierendes Gewerbe. Fachserie 4. Reihe 4.3. Kostenstruktur der Unternehmen, 1995.

put values and unit values. In APPENDIX 2, we present a detailed description of how the Chinese unit values were derived.

The Chinese unit value list is used to derive unit value ratios at sample industry level. At this lowest level of aggregation we weigh unit value ratios with quantities from the commodity list. Then the sample industry unit value ratios (UVRs) were weighted using gross output at the township level and above to get branch UVRs. This gives a benchmark comparison for manufacturing industry at the township level and above, which is consistent with the Chinese time series. This comparison is the comparison with limited coverage.

As a next step we apply the branch UVRs to the larger coverage (at the village level and above). The standard ICOP approach implies that the UVRs are assumed to be representative and can be applied to larger aggregates. As Maddison and van Ark (1988) have shown, it is much safer to make this assumption for prices than for output quantities or value of output.

\section{The Results: Relative LeVels Of PRices, PRODUCTION AND PRODUCTIVITY IN CHINA AND GERMANY}

\section{Unit value ratios and relative price levels}

According to the revised ICOP classification system, we selected 52 sample industries which were grouped into 17 branches of manufacturing. The sample industries on the German side correspond to the four digit industry codes. The Chinese 1995 Industrial Census still does 
not use the classification by industry codes. However, it is possible to organize Chinese industries according to the codes used in the International Standard Industrial Classification (ISIC). In the current study all the 297 products or groups of products were classified into 52 sample industries belonging to 17 branches of manufacturing. The products which were matched in the China-Germany comparison account for 33\% of China's gross value of output and $21.5 \%$ of Germany's output. Thanks to the efforts made in reorganizing the value, quantity, and price information provided in the 1995 Chinese census as well as additional information from other sources, the number of matchings made in the current study is much larger than the previous 1985 benchmark comparison between China and US, for which the matched products represented about $27 \%$ of the gross value of output in China and $17 \%$ of the gross value of output in Germany. TABLE A2.1 (APPENDIX 2) shows the coverage ratios of the present comparison at branch and sample industry.

TABLE 4 shows the UVRs at the branch level. The average UVR (yuan/DM) for manufacturing is 2.89; it can be identified to the exchange rate that makes the parity of industrial product prices between the two countries. This conversion rate is well below the nominal exchange rate (5.8) The comparison of the average UVRs to the nominal exchange rate reveals the Chinese level of industrial prices compared to the German ones. In this case, we find that Chinese prices stand at $49.7 \%$ of the German level. This indicates that the yuan nominal exchange rate undervalues the yuan compared to the parity derived from UVRs. This means that Chinese output converted into DM through the UVR will be much greater than through the nominal exchange rate. From TABLE 4, it becomes apparent that China's relative price level differs across branches. The lowest relative prices are found in traditional branches, such as apparel, leather and shoes.

To discuss the results of the comparison, we present successively the two estimations of gross output, value-added and labour productivity in manufacturing, corresponding to the two data set available for China. These two comparisons have their specific interest. On the one hand, the benchmark comparison using Chinese data on enterprises at the village level and above has the largest possible coverage ( $85 \%$ of output and $75 \%$ of employment) and the comparison of labor productivity at this level makes sense because the German data have a complete coverage. On the other hand, the benchmark comparison based on a narrower coverage ( $67 \%$ of output and $58 \%$ of employment) is useful as it is consistent with the coverage used in time series, which record the trends in China's industrial output and employment.

We will first present the estimations derived from the restricted coverage and then the estimations derived from the broader coverage.î

\section{Benchmark Comparison based on Chinese Data for Firms at the Township Level and above Comparison of output size and structure}

Using the geometric average UVRs (TABLE 4) and the gross value of output at factor cost of China and Germany (from TABLES 1 and 3), we made an evaluation of China's manufacturing 
Table 4 - $\quad$ Unit value ratios (UVR) and price levels by major manufacturing branch in China and Germany, 1995 (excluding the Chineses small firms*)

\begin{tabular}{|c|c|c|c|c|c|}
\hline & & \multicolumn{3}{|c|}{ (Yuan/DM) } & \multirow[b]{2}{*}{$\begin{array}{c}\text { Relative } \\
\text { Price Level } \\
\text { China } \\
\text { (Germany }=100)\end{array}$} \\
\hline & & $\begin{array}{l}\text { At Chinese } \\
\text { Quantity } \\
\text { Weights }\end{array}$ & $\begin{array}{l}\text { At German } \\
\text { Quantity } \\
\text { Weights }\end{array}$ & $\begin{array}{l}\text { Geometric } \\
\text { Average }\end{array}$ & \\
\hline 1. & Food and Kindred Products & 3.7 & 3.6 & 3.6 & 62.2 \\
\hline 2. & Textiles Mill Products & 1.9 & 2.5 & 2.2 & 37.0 \\
\hline 3. & Wearing Apparel & 1.0 & 1.0 & 1.0 & 17.6 \\
\hline 4. & Leather Products and Footwear & 1.2 & 1.0 & 1.1 & 19.1 \\
\hline 5. & Wood Products & 1.9 & 2.1 & 2.0 & 34.6 \\
\hline 6. & Paper Products. Printing \& Publishing & 3.3 & 3.9 & 3.6 & 61.2 \\
\hline 7. & Chemicals \& Allied Products & 2.0 & 3.6 & 2.7 & 46.0 \\
\hline 8. & Petroleum \& Coal Products & 7.1 & 7.0 & 7.0 & 120.9 \\
\hline 9. & Rubber and Plastic Products & 1.8 & 2.9 & 2.3 & 39.4 \\
\hline 10. & Non-Metallic Mineral Products & 2.9 & 2.5 & 2.7 & 46.1 \\
\hline 11. & Basic Metal Products & 5.7 & 2.5 & 3.8 & 64.7 \\
\hline 12. & Fabricated Metal Products & 1.7 & 1.6 & 1.6 & 27.6 \\
\hline 13. & Machinery and Equipment & 0.9 & 3.0 & 1.6 & 27.9 \\
\hline 14. & Transport Equipment & 1.4 & 3.3 & 2.2 & 37.2 \\
\hline \multirow[t]{2}{*}{15.} & Office, Accounting & & & & \\
\hline & and Computing Machinery & 1.6 & 4.4 & 2.7 & 45.7 \\
\hline 16. & Electrical Machinery and Equipment & 0.9 & 3.3 & 1.7 & 29.5 \\
\hline & Other Manufacturing Products & 0.7 & 1.2 & 1.0 & 16.4 \\
\hline & Total Manufacturing: & 2.6 & 3.3 & 2.9 & 49.7 \\
\hline & Official Exchange Rate & & 5.8 & & \\
\hline
\end{tabular}

* IAS enterprises at the township level and above, value data refer to IAS enterprises at the township level and above. Sources: From p. 46 of the Census; price data refer to large and medium enterprises at the township level and above.

output and of Germany's manufacturing output at both Chinese and German prices (TABLE 5). When the geometric average of Chinese and German prices are applied, the Chinese manufacturing output is evaluated at almost 80 per cent of the German manufacturing output. This proportion is twice as large as that obtained from the comparison using the exchange rate.

The comparison highlights the large differences in the structures of output between the two countries, which reflect the contrasted industrial specialisation associated with their different levels of development. China's production of labour intensive products such as textile, clothing, leather and footwear is several times larger than the corresponding German production. By contrast, China's output of capital intensive products such as transport equipment, is less than half the German output.

\section{Productivity level: output per employee}

TABLE 6 allows for a comparison between labour productivity (output per employee) at the branch level between the two countries. Usually, the international comparisons of productivity focus on the per capita value added rather than per capita output, because the measure- 
ment of gross value of output involves the problem of double accounting. However, in the current comparison we also present the measurement of productivity based on gross value of output, as the starting point of the construction of an internationally comparable database, which can be useful in other research works. Because all data for the Chinese side have a narrower coverage, the comparison provides an insight into China's relative manufacturing performance at a level which excludes the small enterprises. Even at this level, labour productivity is quite low in China compared to Germany. It stands on average at $8.6 \%$ of the labour productivity in German manufacturing industry. However there are wide differences across branches: In five sectors, Chinese productivity reaches more than one fourth of the German level (wearing apparel, leather and shoes, office machinery and computers, electrical machinery, and other manufacturing products). In all these branches (except for office machinery) China displays a relative specialisation compared to Germany (TABLE 5). This suggests that China's manufacturing industry is relatively specialised in branches where it has

Table 5 -

Gross value of output by major manufacturing branch in China and Germany, 1995 (excluding the Chinese small firms*)

\begin{tabular}{|c|c|c|c|c|c|c|c|c|}
\hline & & \multicolumn{3}{|c|}{ At Chinese prices } & \multicolumn{3}{|c|}{ At German prices } & \multirow{2}{*}{$\begin{array}{c}\text { Geometric } \\
\text { average } \\
\text { China/ } \\
\text { Germany }\end{array}$} \\
\hline & & China & Germany & $\begin{array}{l}\text { China/ } \\
\text { Germany }\end{array}$ & China & Germany & $\begin{array}{l}\text { China/ } \\
\text { Germany }\end{array}$ & \\
\hline & & \multicolumn{2}{|c|}{ In million Yuan } & $\%$ & \multicolumn{2}{|c|}{ In million DM } & $\%$ & $\%$ \\
\hline 1. & Food and Kindred Products & 626,275 & 898,193 & 69.7 & 171,283 & 250,237 & 68.5 & 69.1 \\
\hline 2. & Textiles Mill Products & 460,400 & 78,990 & 582.9 & 244,117 & 31,981 & 763.3 & 667.0 \\
\hline 3. & Wearing Apparel & 147,015 & 23,338 & 630.0 & 144,647 & 22,526 & 642.1 & 636.0 \\
\hline 4. & Leather Products & & & & & & & \\
\hline & and Footwear & 97,441 & 7,837 & $1,243.3$ & 81,769 & 7,532 & $1,085.7$ & $1,161.8$ \\
\hline 5. & Wood Products & 40,553 & 65,102 & 62.3 & 21,175 & 30,767 & 68.8 & 65.5 \\
\hline 6. & Paper Products, Printing & & & & & & & \\
\hline 7. & $\begin{array}{l}\text { \& Publishing } \\
\text { Chemicals \& Allied }\end{array}$ & 130,399 & 469,462 & 27.8 & 39,674 & 121,195 & 32.7 & 30.2 \\
\hline & Products & 559,099 & 809,930 & 69.0 & 279,478 & 225,774 & 123.8 & 92.4 \\
\hline 8. & Petroleum \& Coal Products & 202,812 & 810,888 & 25.0 & 28,554 & 116,157 & 24.6 & 24.8 \\
\hline 9. & Rubber and Plastic products & 174,753 & 259,198 & 67.4 & 96,902 & 88,811 & 109.1 & 85.8 \\
\hline 10. & Non-Metallic & & & & & & & \\
\hline & Mineral Products & 301,836 & 182,944 & 165.0 & 103,569 & 74,059 & 139.9 & 151.9 \\
\hline & Basic Metal Products & 503,251 & 266,500 & 188.8 & 88,904 & 106,158 & 83.8 & 125.8 \\
\hline 12. & Fabricated Metal Products & 165,072 & 180,729 & 91.3 & 100,073 & 115,254 & 86.8 & 89.1 \\
\hline 13. & Machinery and Equipment & 412,223 & 745,010 & 55.3 & 471,598 & 245,947 & 191.8 & 103.0 \\
\hline 14. & Transport Equipment & 330,328 & $1,020,887$ & 32.4 & 229,474 & 313,691 & 73.2 & 48.7 \\
\hline & $\begin{array}{l}\text { Office, Accounting } \\
\text { and Computing Machinery }\end{array}$ & 35,056 & 133,256 & 26.3 & 21,711 & 30,381 & 71.5 & 43.4 \\
\hline & $\begin{array}{l}\text { Electrical Machinery } \\
\text { and Equipment }\end{array}$ & 557,314 & 849,001 & 65.6 & 626,883 & 255,053 & 245.8 & 127.0 \\
\hline & Other Manufacturing & & & & & & & \\
\hline & Products & 59,709 & 63,460 & 94.1 & 81,297 & 51,375 & 158.2 & 122.0 \\
\hline & Total Manufacturing: & $4,803,536$ & $6,864,724$ & 70.0 & $1,885,656$ & $2,086,897$ & 90.4 & 79.5 \\
\hline
\end{tabular}

* IAS enterprises at the township level and above, value data refer to IAS enterprises at the township level and above. 
the relatively highest level of productivity. All the five branches are also characterised by a strong presence of foreign firms, which is likely to explain their high productivity performance: according to estimations, foreign affiliates contributed to a large share of output in electronic and telecommunication equipment (63\%), leather and shoes (50\%), apparel (43\%), and electrical equipment (27\%) (Lemoine, 2000).

\section{Comparison of manufacturing value-added}

By applying UVRs to value-added by branches of manufacturing, we can go further in the comparison of industrial performance. The results presented in TABLE 7 show that in 1995, China's manufacturing value-added represented about two-thirds of the German level. This ratio is lower than that derived from output comparison, indicating that the share of valueadded in China's industrial output is smaller than in Germany. The structure by branches of the manufacturing value-added confirms that China is strongly specialised in textile and clothing, and leather and shoes. China's value added in these branches represented between four and eight times the German level.

Table 6 -

Gross value of output per person employed in China and Germany, 1995 (excluding the Chinese small firms*)

\begin{tabular}{|c|c|c|c|c|c|c|c|c|}
\hline & & \multicolumn{3}{|c|}{ At Chinese prices } & \multicolumn{3}{|c|}{ At German prices } & \multirow{2}{*}{$\begin{array}{c}\text { Geometric } \\
\text { average } \\
\text { China/ } \\
\text { Germany }\end{array}$} \\
\hline & & China & Germany & $\begin{array}{l}\text { China/ } \\
\text { Germany }\end{array}$ & China & Germany & $\begin{array}{l}\text { China/ } \\
\text { Germany }\end{array}$ & \\
\hline & & \multicolumn{2}{|c|}{ In Yuan } & $\%$ & \multicolumn{2}{|c|}{ In DM } & $\%$ & $\%$ \\
\hline 1. & Food and Kindred Products & 109,721 & $1,592,724$ & 6.9 & 30,008 & 443,734 & 6.8 & 6.8 \\
\hline 2. & Textiles Mill Products & 55,662 & 525,427 & 10.6 & 29,513 & 212,734 & 13.9 & 12.1 \\
\hline 3. & Wearing Apparel & 56,138 & 226,749 & 24.8 & 55,234 & 218,860 & 25.2 & 25.0 \\
\hline \multirow[t]{2}{*}{4.} & Leather Products & & & & & & & \\
\hline & and Footwear & 70,840 & 221,497 & 32.0 & 59,447 & 212,861 & 27.9 & 29.9 \\
\hline 5. & Wood Products & 40,736 & 531,684 & 7.7 & 21,270 & 251,271 & 8.5 & 8.1 \\
\hline \multirow[t]{2}{*}{6.} & Paper Products, Printing & & & & & & & \\
\hline & \& Publishing & 46,957 & 870,978 & 5.4 & 14,287 & 224,849 & 6.4 & 5.9 \\
\hline 7. & Chemicals \& Allied Products & 92,016 & $1,463,804$ & 6.3 & 45,996 & 408,047 & 11.3 & 8.4 \\
\hline 8. & Petroleum \& Coal Products & 294,699 & $32,857,423$ & 0.9 & 41,491 & $4,706,703$ & 0.9 & 0.9 \\
\hline 9. & Rubber and Plastic Products & 70,642 & 708,630 & 10.0 & 39,171 & 242,802 & 16.1 & 12.7 \\
\hline 10. & Non-Metallic Mineral Products & 39,595 & 644,165 & 6.2 & 13,586 & 260,770 & 5.2 & 5.7 \\
\hline 11. & Basic Metal Products & 110,082 & 890,270 & 12.4 & 19,447 & 354,631 & 5.5 & 8.2 \\
\hline 12. & Fabricated Metal Products & 60,932 & 330,594 & 18.4 & 36,940 & 210,827 & 17.5 & 18.0 \\
\hline 13. & Machinery and Equipment & 55,661 & 716,748 & 7.8 & 63,679 & 236,617 & 26.9 & 14.5 \\
\hline 14. & Transport Equipment & 89,165 & $1,139,516$ & 7.8 & 61,941 & 350,142 & 17.7 & 11.8 \\
\hline & Office, Accounting & & & & & & & \\
\hline & $\begin{array}{l}\text { and Computing Machinery } \\
\text { Electrical Machinery }\end{array}$ & 346,746 & $2,000,238$ & 17.3 & 214,747 & 456,030 & 47.1 & 28.6 \\
\hline & and Equipment & 106,423 & 841,150 & 12.7 & 119,708 & 252,694 & 47.4 & 24.5 \\
\hline \multirow[t]{2}{*}{17.} & Other Manufacturing Products & 50,859 & 254,186 & 20.0 & 69,247 & 205,779 & 33.7 & 26.0 \\
\hline & Total Manufacturing: & 75,634 & $1,002,332$ & 7.6 & 29,691 & 304,712 & 9.7 & 8.6 \\
\hline
\end{tabular}

* IAS enterprises at the township level and above. 
Table 7 - Gross value added by major manufacturing branch, China and Germany, 1995 (excluding the Chinese small firms*)

\begin{tabular}{|c|c|c|c|c|c|c|c|c|}
\hline & & \multicolumn{3}{|c|}{ At Chinese prices } & \multicolumn{3}{|c|}{ At German prices } & \multirow{2}{*}{$\begin{array}{c}\text { Geometric } \\
\text { average } \\
\text { China/ } \\
\text { Germany }\end{array}$} \\
\hline & & China & Germany & $\begin{array}{l}\text { China/ } \\
\text { Germany }\end{array}$ & China & Germany & $\begin{array}{l}\text { China/ } \\
\text { Germany }\end{array}$ & \\
\hline & & \multicolumn{2}{|c|}{ Million Yuan } & $\%$ & \multicolumn{2}{|c|}{ Million DM } & $\%$ & $\%$ \\
\hline 1. & Food and Kindred Products & 170,735 & 182,719 & 93.4 & 46,695 & 50,906 & 91.7 & 92.6 \\
\hline 2. & Textiles Mill Products & 89,845 & 24,599 & 365.2 & 47,638 & 9,959 & 478.3 & 418.0 \\
\hline 3. & Wearing Apparel & 34,729 & 6,344 & 547.4 & 34,170 & 6,123 & 558.0 & 552.7 \\
\hline 4. & $\begin{array}{l}\text { Leather Products } \\
\text { and Footwear }\end{array}$ & 20,147 & & 922.1 & 16.907 & & & \\
\hline 5. & Wood Products & 9,508 & 21,636 & 44.0 & 4,965 & 10,225 & 48.6 & 46.2 \\
\hline 6. & Paper Products, Printing & & & & & & & \\
\hline & \& Publishing & 29,506 & 173,228 & 17.0 & 8,977 & 44,720 & 20.1 & 18.5 \\
\hline 7. & Chemicals \& Allied Products & 141,038 & 262,632 & 53.7 & 70,501 & 73,211 & 96.3 & 71.9 \\
\hline 8. & Petroleum \& Coal Products & 56,133 & 26,948 & 208.3 & 7,903 & 3,860 & 204.7 & 206.5 \\
\hline 9. & Rubber and Plastic Products & 36,343 & 93,824 & 38.7 & 20,153 & 32,148 & 62.7 & 49.3 \\
\hline & Non-Metallic Mineral & & & & & & & \\
\hline & Products & 89,991 & 71658 & 125.6 & 30,879 & 29,008 & 106.5 & 115.6 \\
\hline & Basic Metal Products & 135,533 & 79,324 & 170.9 & 23,943 & 31,598 & 75.8 & 113.8 \\
\hline & Fabricated Metal Products & 38,394 & 72,433 & 53.0 & 23,276 & 46,192 & 50.4 & 51.7 \\
\hline & Machinery and Equipment & 111,916 & 288,205 & 38.8 & 128,036 & 95,144 & 134.6 & 72.3 \\
\hline & Transport Equipment & 80,512 & 306,139 & 26.3 & 55,930 & 94,068 & 59.5 & 39.5 \\
\hline & $\begin{array}{l}\text { Office, Accounting } \\
\text { and Computing Machinery }\end{array}$ & 9,209 & 32,800 & 28.1 & 5,703 & 7,478 & 76.3 & 46.3 \\
\hline & Electrical Machinery & & & & & & & \\
\hline & and Equipment & 136,137 & 304,261 & 44.7 & 153,131 & 91,405 & 167.5 & 86.6 \\
\hline 17. & Other Manufacturing & & & & & & & \\
\hline & Products & 14,761 & 23,026 & 64.1 & 20,098 & 18,641 & 107.8 & 83.1 \\
\hline & Total Manufacturing: & $1,204,437$ & $2,127,566$ & 56.6 & 472,809 & 646,787 & 73.1 & 64.3 \\
\hline
\end{tabular}

* IAS enterprises at the township level and above.

The comparisons between China and Germany in terms of value added per employee are presented in TABLE 8. For total manufacturing, if the data used are limited to the enterprises at the township and above, Chinese productivity reached 7 per cent of the German level. This should be regarded as a major finding from the current comparison. At the branch level, there is quite large variation in relative productivity performance. Highest labour productivity is found in office, accounting and computing machinery $30.5 \%$ of the German level), leather products and footwear (22.2\%), wearing apparel $(21.7 \%)$, other manufacturing products (17.7\%) and electrical machinery and equipment (16.7\%). Relatively low productivity is found in paper products, printing \& publishing (3.6\%), non-metallic mineral products $(4.3 \%)$, and wood products $(5.7 \%)$.

Ren, Szirmai and Bai (2002) provided a new benchmark comparison between China and the USA using the same framework. TABLE 9 was reproduced from that study, which was based on the Chinese basic data on the enterprises at the township level and above. Therefore, in 
Gross value added per person employed in China and Germany, 1995 (excluding the Chinese small firms*)

\begin{tabular}{|c|c|c|c|c|c|c|c|c|}
\hline & & \multicolumn{3}{|c|}{ At Chinese prices } & \multicolumn{3}{|c|}{ At German prices } & \multirow{2}{*}{$\begin{array}{c}\text { Geometri } \\
\text { average } \\
\text { China/ } \\
\text { Germany }\end{array}$} \\
\hline & & China & Germany & $\begin{array}{l}\text { China/ } \\
\text { Germany }\end{array}$ & China & Germany & $\begin{array}{l}\text { China/ } \\
\text { Germany }\end{array}$ & \\
\hline & & \multicolumn{2}{|c|}{ In Yuan } & $\%$ & \multicolumn{2}{|c|}{ In DM } & $\%$ & $\%$ \\
\hline 1. & Food and Kindred Products & 29,912 & 324,008 & 9.2 & 8,181 & 90,269 & 9.1 & 9.2 \\
\hline 2. & Textiles Mill Products & 10,862 & 163,627 & 6.6 & 5,759 & 66,249 & 8.7 & 7.6 \\
\hline 3. & Wearing Apparel & 13,261 & 61,637 & 21.5 & 13,048 & 59,493 & 21.9 & 21.7 \\
\hline 4. & Leather Products & & & & & & & \\
\hline & and Footwear & 14,647 & 61,749 & 23.7 & 12,291 & 59,342 & 20.7 & 22.2 \\
\hline 5. & Wood Products & 9,551 & 176,699 & 5.4 & 4,987 & 83,507 & 6.0 & 5.7 \\
\hline 6. & Paper Products, Printing & & & & & & & \\
\hline & \& Publishing & 10,625 & 321,386 & 3.3 & 3,233 & 82,968 & 3.9 & 3.6 \\
\hline 7. & Chemicals \& Allied & & & & & & & \\
\hline & Products & 23,212 & 474,661 & 4.9 & 11,603 & 132,315 & 8.8 & 6.6 \\
\hline 8. & Petroleum \& Coal & & & & & & & \\
\hline & Products & 81,565 & $1,091,924$ & 7.5 & 11,483 & 156,414 & 7.3 & 7.4 \\
\hline 9. & Rubber and Plastic & & & & & & & \\
\hline & Products & 14,691 & 256,510 & 5.7 & 8,146 & 87,890 & 9.3 & 7.3 \\
\hline 10. & Non-Metallic Mineral & & & & & & & \\
\hline & Products & 11,805 & 252,314 & 4.7 & 4,051 & 102,142 & 4.0 & 4.3 \\
\hline 11. & Basic Metal Products & 29,647 & 264,990 & 11.2 & 5,237 & 105,556 & 5.0 & 7.5 \\
\hline 12. & Fabricated Metal Products & 14,172 & 132,497 & 10.7 & 8,592 & 84,496 & 10.2 & 10.4 \\
\hline 13. & Machinery and Equipment & 15,112 & 277,272 & 5.5 & 17,288 & 91,535 & 18.9 & 10.2 \\
\hline 14. & Transport Equipment & 21,732 & 341,713 & 6.4 & 15,097 & 104,999 & 14.4 & 9.6 \\
\hline & $\begin{array}{l}\text { Office, Accounting } \\
\text { and Computing Machinery }\end{array}$ & 91,088 & 492,350 & 18.5 & 56,413 & 112,250 & 50.3 & 30.5 \\
\hline & $\begin{array}{l}\text { Electrical Machinery } \\
\text { and Equipment }\end{array}$ & 25996 & 301,448 & 8.6 & 29,241 & 90,560 & 32.3 & 16.7 \\
\hline 17. & Other Manufacturing & & & & & & & \\
\hline & products & 12,573 & 92,229 & 13.6 & 17,119 & 74,665 & 22.9 & 17.7 \\
\hline & Total Manufacturing: & 18,964 & 310,650 & 6.1 & 7,445 & 94,439 & 7.9 & 6.9 \\
\hline
\end{tabular}

* IAS enterprises at the township level and above.

terms of coverage, the results in TABLE 9 are comparable to those in TABLE 8. Aggregate value added per person employed in Chinese manufacturing is 5.2 per cent of the US level in 1995, while it is 6.9 per cent of the German level in the same year.

\section{Comparison based on Chinese data for enterprises at the vil- lage level and above}

We will now turn to the comparison based on data with the broadest coverage.

\section{Comparison of output and output per employee}

TABLE 10 shows the value of output comparison by manufacturing branches between China and Germany and TABLE 11 shows the comparisons in terms of output per employee in manufacturing branches. 
Table 9 - Gross value added per person employed, in China and the USA, 1995 (excluding the Chinese small firms*)

\begin{tabular}{|c|c|c|c|c|c|c|c|c|}
\hline & & \multicolumn{3}{|c|}{ At Chinese prices } & \multicolumn{3}{|c|}{ At USA Prices } & \multirow{2}{*}{$\begin{array}{c}\text { Geometric } \\
\text { average } \\
\text { China/ } \\
\text { USA }\end{array}$} \\
\hline & & China & USA & $\begin{array}{l}\text { China/ } \\
\text { USA }\end{array}$ & China & USA & $\begin{array}{l}\text { China/ } \\
\text { USA }\end{array}$ & \\
\hline & & \multicolumn{2}{|c|}{ In RMB } & $\%$ & \multicolumn{2}{|c|}{$\ln \$$} & $\%$ & $\%$ \\
\hline 1. & Food and Kindred Products & 19443 & 454950 & 4.3 & 3328 & 78015 & 4.3 & 4.3 \\
\hline 2. & Textiles Mill Products & 9970 & 194634 & 5.1 & 2526 & 36978 & 6.8 & 5.9 \\
\hline 3. & Wearing apparel & 12342 & 238148 & 5.2 & 3642 & 41594 & 8.8 & 6.7 \\
\hline 4. & Leather products and Footwear & 12608 & 104976 & 12.0 & 5652 & 47125 & 12.0 & 12.0 \\
\hline 5. & Wood products & 9031 & 160654 & 5.6 & 4004 & 43714 & 9.2 & 7.2 \\
\hline \multirow[t]{2}{*}{6.} & Paper Products, Printing & & & & & & & \\
\hline & \& Publishing & 12395 & 308119 & 4.0 & 2268 & 58810 & 3.9 & 3.9 \\
\hline 7. & Chemicals \& Allied Products & 18542 & 1127896 & 1.6 & 2612 & 144456 & 1.8 & 1.7 \\
\hline 8. & Petroleum \& Coal Products & 63179 & 1631582 & 3.9 & 7997 & 202622 & 3.9 & 3.9 \\
\hline 9. & Rubber and Plastic products & 12818 & 326137 & 3.9 & 1877 & 46889 & 4.0 & 4.0 \\
\hline 10. & Non-Metallic Mineral Products & 10698 & 97925 & 10.9 & 4547 & 58013 & 7.8 & 9.3 \\
\hline 11. & Basic Metal Products & 28647 & 544314 & 5.3 & 5382 & 74634 & 7.2 & 6.2 \\
\hline 12. & Fabricated metal products & 14678 & 380260 & 3.9 & 7171 & 59500 & 12.1 & 6.8 \\
\hline & Machinery and Equipment & 11700 & 155567 & 7.5 & 7792 & 63160 & 12.3 & 9.6 \\
\hline 14. & Transport equipment & 19096 & 79961 & 23.9 & 19404 & 81249 & 23.9 & 23.9 \\
\hline & Office, Accounting & & & & & & & \\
\hline & and Computing machinery & 56061 & 632639 & 8.9 & 22629 & 95525 & 23.7 & 14.5 \\
\hline & Electrical Machinery & & & & & & & \\
\hline & and Equipment & 22562 & 254292 & 8.9 & 7565 & 75989 & 10.0 & 9.4 \\
\hline & Other manufacturing products & 10189 & 246035 & 4.1 & 2437 & 50836 & 4.8 & 4.5 \\
\hline & Total Manufacturing: & 15696 & 327839 & 4.8 & 3754 & 67739 & 5.5 & 5.2 \\
\hline
\end{tabular}

* IAS enterprises at the township level and above.

When industrial activity of firms at the village level is included, China's industrial output is slightly larger than Germany's (102\%). At the branch level, the activity of small firms appears to be especially important in wearing apparel, leather and shoes, wood and paper products. Taking their production into account thus raises China's relative specialisation in traditional labour intensive sectors, in comparison to Germany. In wearing apparel, Chinese production is thus almost ten times Germany's production level and in leather and shoes, it reaches more than 16 times Germany's level.

The level of output per employee in China is 7.4\% the German level in this extensive coverage (against $8.6 \%$ in the restricted coverage). Much higher productivity performance is found in the same branches (apparel, leather and shoes, electrical machinery, etc.).

\section{Comparison of value-added and value-added per employee}

TABLE 12 presents the bilateral comparison of value added in manufacturing between China and Germany for 1995. China's total manufacturing value-added, even in this broad coverage, remains smaller than Germany's (standing at 71\%). This indicates that the share of value-added in output is much smaller in China's industry than in Germany's industry, especially when small firms are taken into account. Value-added represents $20 \%$ of output in the 
Table 10 - Gross value of output by major manufacturing branch in China and Germany, 1995 (including the Chinese small firms*)

\begin{tabular}{|c|c|c|c|c|c|c|c|c|}
\hline & & \multicolumn{3}{|c|}{ At Chinese prices } & \multicolumn{3}{|c|}{ At German prices } & \multirow{2}{*}{$\begin{array}{c}\text { Geometric } \\
\text { average } \\
\text { China/ } \\
\text { Germany }\end{array}$} \\
\hline & & China & Germany & $\begin{array}{l}\text { China/ } \\
\text { Germany }\end{array}$ & China & Germany & $\begin{array}{l}\text { China/ } \\
\text { Germany }\end{array}$ & \\
\hline & & \multicolumn{2}{|c|}{ In million Yuan } & $\%$ & \multicolumn{2}{|c|}{ In million DM } & $\%$ & $\%$ \\
\hline 1. & Food and Kindred Products & 731,817 & 898,193 & 81.5 & 200,148 & 250,237 & 80.0 & 80.7 \\
\hline 2. & Textiles Mill Products & 555,730 & 78,990 & 703.6 & 294,663 & 31,981 & 921.4 & 805.1 \\
\hline 3. & Wearing Apparel & 223,257 & 23,338 & 956.6 & 219,660 & 22,526 & 975.2 & 965.9 \\
\hline \multirow[t]{2}{*}{4.} & Leather Products & & & & & & & \\
\hline & and Footwear & 140,777 & 7,837 & $1,796.3$ & 118,135 & 7,532 & $1,568.5$ & $1,678.5$ \\
\hline 5. & Wood Products & 70,053 & 65,102 & 107.6 & 36,578 & 30,767 & 118.9 & 113.1 \\
\hline \multirow[t]{2}{*}{6.} & Paper Products, Printing & & & & & & & \\
\hline & \& Publishing & 199,510 & 469,462 & 42.5 & 60,702 & 121,195 & 50.1 & 46.1 \\
\hline 7. & Chemicals \& Allied Products & 634,149 & 809,930 & 78.3 & 316,994 & 225,774 & 140.4 & 104.9 \\
\hline 8. & Petroleum \& Coal Products & 204,732 & 810,888 & 25.3 & 28,824 & 116,157 & 24.8 & 25.0 \\
\hline 9. & Rubber and Plastic Products & 250,812 & 259,198 & 96.8 & 139,078 & 88,811 & 156.6 & 123.1 \\
\hline \multirow[t]{2}{*}{10.} & Non-Metallic Mineral & & & & & & & \\
\hline & Products & 496,561 & 182,944 & 271.4 & 170,384 & 74,059 & 230.1 & 249.9 \\
\hline 11. & Basic Metal Products & 579,001 & 266,500 & 217.3 & 102,286 & 106,158 & 96.4 & 144.7 \\
\hline 12. & Fabricated Metal Products & 271,971 & 180,729 & 150.5 & 164,880 & 115,254 & 143.1 & 146.7 \\
\hline 13. & Machinery and Equipment & 540,770 & 745,010 & 72.6 & 618,661 & 245,947 & 251.5 & 135.1 \\
\hline 14. & Transport Equipment & 369,806 & $1,020,887$ & 36.2 & 256,898 & 313,691 & 81.9 & 54.5 \\
\hline \multirow{5}{*}{$\begin{array}{l}15 . \\
16 . \\
17 .\end{array}$} & $\begin{array}{l}\text { Office, Accounting } \\
\text { and Computing Machinery }\end{array}$ & 43,443 & 133,256 & 32.6 & 26,905 & 30,381 & 88.6 & 53.7 \\
\hline & $\begin{array}{l}\text { Electrical Machinery } \\
\text { and Equipment }\end{array}$ & 556,036 & 849,001 & 65.5 & 625,446 & 255,053 & 245.2 & 126.7 \\
\hline & Other Manufacturing & & & & & & & \\
\hline & Products & 274,688 & 63,460 & 432.9 & 374,000 & 51,375 & 728.0 & 561.3 \\
\hline & Total Manufacturing: & $6,143,114$ & $6,864,724$ & 89.5 & $2,411,516$ & $2,086,897$ & 115.6 & 101.7 \\
\hline
\end{tabular}

* Data on enterprises at the village level and above with sales greater than 1 million Yuan.

broadest coverage of China's manufacturing industry, $25 \%$ in the limited coverage, and represents $31 \%$ of Germany's industry.

The comparison of labor productivity based on value-added per employee is presented in TABLE 13. This should be regarded as another major result from the current study. The average level of productivity based on value-added in China is $5.2 \%$ of the German level in this broad coverage (against $6.9 \%$ in the restricted coverage). The highest labor productivity is found in wearing apparel (19.7\% of Germany's level) and office machinery $(19.2 \%)$. The lowest level of productivity is found in paper products (3.3\% of Germany's level) and nonmetallic mineral products (3.7\%).

\section{CONCLUDING REMARKS}

This comparative study marks a new step forward in estimating China's manufacturing output and productivity in an international perspective. The findings of this study can be com- 
Table 11 -

Gross value of output per person employed in China and Germany, 1995 (including the Chinese small firms*)

\begin{tabular}{|c|c|c|c|c|c|c|c|c|}
\hline & & \multicolumn{3}{|c|}{ At Chinese prices } & \multicolumn{3}{|c|}{ At German prices } & \multirow{2}{*}{$\begin{array}{c}\text { Geometric } \\
\text { average } \\
\text { China/ } \\
\text { Germany }\end{array}$} \\
\hline & & China & Germany & $\begin{array}{l}\text { China/ } \\
\text { Germany }\end{array}$ & China & Germany & $\begin{array}{l}\text { China/ } \\
\text { Germany }\end{array}$ & \\
\hline & & \multicolumn{2}{|c|}{ In Yuan } & $\%$ & \multicolumn{2}{|c|}{ In DM } & $\%$ & $\%$ \\
\hline 1. & Food and Kindred Products & 90,792 & $1,592,724$ & 5.7 & 24,831 & 443,734 & 5.6 & 5.7 \\
\hline 2. & Textiles Mill Products & 54,806 & 525,427 & 10.4 & 29,060 & 212,734 & 13.7 & 11.9 \\
\hline 3. & Wearing Apparel & 53,300 & 226,749 & 23.5 & 52,441 & 218,860 & 24.0 & 23.7 \\
\hline \multirow[t]{2}{*}{4.} & Leather Products & & & & & & & \\
\hline & and Footwear & 59,510 & 221,497 & 26.9 & 49,939 & 212,861 & 23.5 & 25.1 \\
\hline 5. & Wood Products & 43,200 & 531,684 & 8.1 & 22,557 & 251,271 & 9.0 & 8.5 \\
\hline \multirow[t]{2}{*}{6.} & Paper Products, Printing & & & & & & & \\
\hline & \& Publishing & 49,591 & 870,978 & 5.7 & 15,088 & 224,849 & 6.7 & 6.2 \\
\hline 7. & Chemicals \& Allied Products & 84,252 & $1,463,804$ & 5.8 & 42,115 & 408,047 & 10.3 & 7.7 \\
\hline 8. & Petroleum \& Coal Products & 215,711 & $32,857,423$ & 0.7 & 30,370 & 4706,703 & 0.7 & 0.7 \\
\hline 9. & Rubber and Plastic Products & 65,148 & 708,630 & 9.2 & 36,125 & 242,802 & 14.9 & 11.7 \\
\hline 10. & Non-Metallic Mineral Products & 35,859 & 644,165 & 5.6 & 12,304 & 260,770 & 4.7 & 5.1 \\
\hline 11. & Basic Metal Products & 99,427 & 890,270 & 11.2 & 17,565 & 354,631 & 5.0 & 7.4 \\
\hline 12. & Fabricated Metal Products & 62,666 & 330,594 & 19.0 & 37,991 & 210,827 & 18.0 & 18.5 \\
\hline 13. & Machinery and Equipment & 52,772 & 716,748 & 7.4 & 60,374 & 236,617 & 25.5 & 13.7 \\
\hline 14. & Transport Equipment & 77,152 & $1,139,516$ & 6.8 & 53,596 & 350,142 & 15.3 & 10.2 \\
\hline & Office, Accounting & & & & & & & \\
\hline & $\begin{array}{l}\text { and Computing machinery } \\
\text { Electrical Machinery }\end{array}$ & 214,955 & $2,000,238$ & 10.8 & 133,126 & 456,030 & 29.2 & 17.7 \\
\hline & and Equipment & 90,851 & 841,150 & 10.8 & 102,192 & 252,694 & 40.4 & 20.9 \\
\hline \multirow[t]{2}{*}{17.} & Other Manufacturing Products & 41,186 & 254,186 & 16.2 & 56,076 & 205,779 & 27.3 & 21.0 \\
\hline & Total Manufacturing: & 64,822 & $1,002,332$ & 6.5 & 25,446 & 304,712 & 8.4 & 7.4 \\
\hline
\end{tabular}

* Data on enterprises at the village level and above with sales greater than 1 million Yuan.

pared with the results of the comparisons made between China and the US for 1985 and 1995, and they are generally consistent with those derived from these comparisons. The present study confirms the labour intensive nature of Chinese production. In 1995, Chinese labor productivity in manufacturing reached 6.9 percent of the German level when small firms were excluded from the Chinese data, and 5.2 percent of the German level when they were included. This is higher than the figures derived from the 1995 comparison with the US, which puts China's productivity between 5.2 percent (excluding small firms) and 4.7 percent (including them) of the US productivity level.

Also remarkable is the branch variation around the mean. The present study finds that the relative productivity performance at the branch level varies considerably. When small Chinese firms are excluded, the best performance is recorded in office and computing machinery, with productivity reaching 30 percent of the German level, and the worst performance is recorded in paper products, with productivity representing 3.6 per cent of the German level. The ranking is somewhat different when small Chinese firms are included. 
Table 12 - Gross value added by major manufacturing branch in China and Germany, 1995 (including the Chinese small firms*)

\begin{tabular}{|c|c|c|c|c|c|c|c|c|}
\hline & & \multicolumn{3}{|c|}{ At Chinese prices } & \multicolumn{3}{|c|}{ At German prices } & \multirow{2}{*}{$\begin{array}{c}\text { Geometri } \\
\text { average } \\
\text { China/ } \\
\text { Germany }\end{array}$} \\
\hline & & China & Germany & $\begin{array}{l}\text { China/ } \\
\text { Germany }\end{array}$ & China & Germany & $\begin{array}{l}\text { China/ } \\
\text { Germany }\end{array}$ & \\
\hline & & \multicolumn{2}{|c|}{ In Yuan } & $\%$ & \multicolumn{2}{|c|}{ In DM } & $\%$ & $\%$ \\
\hline 1. & Food and Kindred Products & 147,746 & 182,719 & 80.9 & 40,408 & 50,906 & 79.4 & 80.1 \\
\hline 2. & Textiles Mill Products & 93,184 & 24,599 & 378.8 & 49,409 & 9,959 & 496.1 & 433.5 \\
\hline 3. & Wearing Apparel & 50,405 & 6,344 & 794.5 & 49,593 & 6,123 & 809.9 & 802.2 \\
\hline \multirow[t]{2}{*}{4.} & Leather Products and & & & & & & & \\
\hline & Footwear & 18,750 & 2,185 & 858.2 & 15,735 & 2,100 & 749.4 & 801.9 \\
\hline \multirow{3}{*}{$\begin{array}{l}5 . \\
6 .\end{array}$} & Wood Products & 18,032 & 21,636 & 83.3 & 9,415 & 10,225 & 92.1 & 87.6 \\
\hline & Paper Products, Printing & & & & & & & \\
\hline & \& Publishing & 39,111 & 173,228 & 22.6 & 11,900 & 44,720 & 26.6 & 24.5 \\
\hline 7. & Chemicals \& Allied Products & 123,229 & 262,632 & 46.9 & 61,599 & 73,211 & 84.1 & 62.8 \\
\hline 8. & Petroleum \& Coal Products & 59,963 & 26,948 & 222.5 & 8,442 & 3,860 & 218.7 & 220.6 \\
\hline 9. & Rubber and Plastic Products & 49,697 & 93,824 & 53.0 & 27,557 & 32,148 & 85.7 & 67.4 \\
\hline \multirow[t]{2}{*}{10.} & Non-Metallic Mineral & & & & & & & \\
\hline & Products & 140,212 & 71,658 & 195.7 & 48,111 & 29,008 & 165.9 & 180.1 \\
\hline 11. & Basic Metal Products & 123,873 & 79,324 & 156.2 & 21,883 & 31,598 & 69.3 & 104.0 \\
\hline 12. & Fabricated Metal Products & 63,703 & 72,433 & 88.0 & 38,619 & 46,192 & 83.6 & 85.8 \\
\hline 13. & Machinery and Equipment & 111,145 & 288,205 & 38.6 & 127,154 & 95,144 & 133.6 & 71.8 \\
\hline 14. & Transport Equipment & 91,532 & 306,139 & 29.9 & 63,586 & 94,068 & 67.6 & 45.0 \\
\hline \multirow{6}{*}{$\begin{array}{l}15 . \\
16 . \\
17 .\end{array}$} & Office, Accounting & & & & & & & \\
\hline & and Computing Machinery & 11,577 & 32,800 & 35.3 & 7,170 & 7,478 & 95.9 & 58.2 \\
\hline & $\begin{array}{l}\text { Electrical Machinery } \\
\text { and Equipment }\end{array}$ & 128,146 & 304,261 & 42.1 & 144,142 & 91,405 & 157.7 & 81.5 \\
\hline & Other Manufacturing & & & & & & & \\
\hline & Products & 70,919 & 23,026 & 308.0 & 96,560 & 18,641 & 518.0 & 399.4 \\
\hline & Total Manufacturing: & $1,341,225$ & $2,127,566$ & 63.0 & 526,506 & 646,787 & 81.4 & 71.6 \\
\hline
\end{tabular}

* Data on enterprises at the village level and above with sales greater than 1 million Yuan.

Labour productivity reaches 19.7 percent of the German level in wearing apparel and falls to 3.3 per cent in paper products.

The labour productivity comparison based on extensive coverage (at the village level and above) indicates a comparatively lower performance in China's manufacturing activity. Although this estimate implies several adjustments and assumptions, and is therefore subject to errors, it may be closer to the reality than the higher estimate based on the limited coverage.

Concerning China's competitiveness, a first conclusion that can be drawn from this study is that the conversion rate derived from the comparison of production prices (unit values) in manufacturing indicates that the nominal exchange rate strongly undervalued the yuan in 1995 and led the level of Chinese production prices to stand well below the German price level. A second observation is that the comparison of industrial output structures and relative labour productivity shows that China's manufacturing industry is specialised in branches in which it has a relatively high level of productivity (apparel, leather and shoes, electrical and 
Table 13 -

Gross value added per person employed, China and Germany, 1995 (including the Chinese small firms*)

\begin{tabular}{|c|c|c|c|c|c|c|c|c|}
\hline & & \multicolumn{3}{|c|}{ At Chinese prices } & \multicolumn{3}{|c|}{ At German prices } & \multirow{2}{*}{$\begin{array}{c}\text { Geometric } \\
\text { average } \\
\text { China/ } \\
\text { Germany }\end{array}$} \\
\hline & & China & Germany & $\begin{array}{l}\text { China/ } \\
\text { Germany }\end{array}$ & China & Germany & $\begin{array}{l}\text { China/ } \\
\text { Germany }\end{array}$ & \\
\hline & & \multicolumn{2}{|c|}{ In Yuan } & $\%$ & \multicolumn{2}{|c|}{ In DM } & $\%$ & $\%$ \\
\hline 1. & Food and Kindred Products & 18,330 & 324,008 & 5.7 & 5,013 & 90,269 & 5.6 & 5.6 \\
\hline 2. & Textiles Mill Products & 9,190 & 163,627 & 5.6 & 4,873 & 66,249 & 7.4 & 6.4 \\
\hline 3. & Wearing Apparel & 12,034 & 61,637 & 19.5 & 11,840 & 59,493 & 19.9 & 19.7 \\
\hline \multirow[t]{2}{*}{4.} & Leather Products & & & & & & & \\
\hline & and Footwear & 7,926 & 61,749 & 12.8 & 6,651 & 59,342 & 11.2 & 12.0 \\
\hline 5. & Wood Products & 11,120 & 176,699 & 6.3 & 5,806 & 83,507 & 7.0 & 6.6 \\
\hline \multirow[t]{2}{*}{6.} & Paper Products, Printing \& & & & & & & & \\
\hline & Publishing & 9,722 & 321386 & 3.0 & 2,958 & 82,968 & 3.6 & 3.3 \\
\hline 7. & Chemicals \& Allied Products & 16,372 & 474661 & 3.5 & 8,184 & 132,315 & 6.2 & 4.6 \\
\hline 8. & Petroleum \& Coal Products & 63,179 & 1091924 & 5.8 & 8,895 & 156,414 & 5.7 & 5.7 \\
\hline 9. & Rubber and Plastic Products & 12,909 & 256510 & 5.0 & 7,158 & 87,890 & 8.1 & 6.4 \\
\hline \multirow[t]{2}{*}{10.} & Non-Metallic Mineral & & & & & & & \\
\hline & Products & 10,125 & 252,314 & 4.0 & 3,474 & 102,142 & 3.4 & 3.7 \\
\hline & Basic Metal Products & 21,272 & 264,990 & 8.0 & 3,758 & 105,556 & 3.6 & 5.4 \\
\hline & Fabricated Metal Products & 14,678 & 132,497 & 11.1 & 8,898 & 84,496 & 10.5 & 10.8 \\
\hline & Machinery and Equipment & 10,846 & 277,272 & 3.9 & 12,409 & 91,535 & 13.6 & 7.3 \\
\hline & Transport Equipment & 19,096 & 341,713 & 5.6 & 13,266 & 104,999 & 12.6 & 8.4 \\
\hline \multirow{6}{*}{$\begin{array}{l}15 . \\
16 . \\
17 .\end{array}$} & Office, Accounting and & & & & & & & \\
\hline & Computing Machinery & 57,285 & 492,350 & 11.6 & 35,478 & 112,250 & 31.6 & 19.2 \\
\hline & $\begin{array}{l}\text { Electrical Machinery } \\
\text { and Equipment }\end{array}$ & 20,938 & 301,448 & 7.0 & 23,551 & 90,560 & 26.0 & 13.4 \\
\hline & Other Manufacturing & & & & & & & \\
\hline & Products & 10,633 & 92,229 & 11.5 & 14,478 & 74,665 & 19.4 & 15.0 \\
\hline & Total Manufacturing: & 14,153 & 310,650 & 4.6 & 5,556 & 94,439 & 5.9 & 5.2 \\
\hline
\end{tabular}

* Data on enterprises at the village level and above with sales greater than 1 million Yuan.

electronic goods). A third observation is that these branches are also those in which China appears to be the most competitive internationally, as evidenced by its strong positions in world product markets (see Lemoine and Ünal-Kesenci in this issue). Finally, these branches are also characterised by a strong presence of foreign firms (see $\mathrm{Yu}$ and Démurger in this issue) which suggests that foreign direct investment plays an important part in the productivity performance of China's manufacturing industry ${ }^{4}$.

R.R. \& B.M.

4. We are grateful to Professor Szirmai for his comments and suggestions and for allowing us to incorporate the findings from his project on China and US comparisons into the present paper. We are grateful to Françoise Lemoine of CEPII for initiating this study and making this project proceeding. We benefited from discussions held during the workshop on "The Competitiveness of China's Economy" held in CEPII, and from the CEPII experience in bilateral comparisons of productivity. Nanno Mulder's and Li Shantong's comments were very helpful. We thank Zheng Haitao for research assistance. 


\section{Appendix 1 \\ ICOP Methods}

This annex is derived from Timmer et al. (2001).

A major task in the ICOP approach to manufacturing is to derive industry-specific conversion factors on the basis of relative product prices. As a first step, unit values (uv) are derived by dividing ex-factory output values $(0)$ by produced quantities $(q)$ for each product $i$ in each country

$u v_{i}=\frac{o_{i}}{q_{i}}$

In a bilateral comparison, broadly defined products with similar characteristics are matched, for each matched product, the ratio of the unit values in both countries is taken. This unit value ratio (UVR) is given by:

$U V R_{i}^{x u}=\frac{u v_{i}^{x}}{u v_{i}^{u}}$

with $x$ representing the country being compared, and $u$ being the base country.

Product UVRs are used to derive an aggregate UVR for manufacturing branches and total manufacturing in a stepwise weighting procedure. There are four levels which are being distinguished: products, industries, branches and total manufacturing. These levels correspond to the levels distinguished in the International Standard Industrial Classification (ISIC rev 3). ICOP industries consist of four-digit ISIC industries, and ICOP branches consist of two-digit divisions. The total manufacturing output is the sum of branch output, which is the sum of industries' output. The output value of an industry is the sum of output values of its products.

Two UVRs are derived at each level. A Laspeyres UVR is calculated by using base country weights and a Paasche UVR by using weights for the other country. The Laspeyres and Paasche indices are combined into a Fisher index when a single currency conversion factor is required. It is defined as the geometric average of the Laspeyres and the Paasche.

\section{Aggregation Step One: Industry LeVel UVRs}

The industry UVR (UVR $)$ is given by the mean of the UVRs of the sampled products. Product UVRs are weighted by their output value, as more important products should have a bigger weight in the industry UVR:

$U V R_{j}=\sum_{i=1}^{I_{j}} w_{i j} U V R_{i j}$

with $i=1, . ., l_{j}$ representnig the matched products in industry $j ; w_{i j}=o_{i j} / o_{j}^{M}$ representing the output share of the $i^{\text {th }}$ commodity in industry $j$ in total matched output; and $o_{j}^{M}=\sum_{i=1}^{l_{j}} o_{i j}$ representing the total matched value of output in industry $j$. In bilateral comparisons the weights of the base country $(u)$ or the other country $(x)$ can be used. The use of the base country value weights leads to the Laspeyres index. Substituting base country weights in (3) gives: 
$U V R_{j}^{x u(u)}=\sum_{i=1}^{l_{j}} w_{i j}^{u(u)} U V R_{i j}$

with $w_{i j}^{u(u)}=o_{i j}^{u(u)} / O_{j}^{M u(u)} ; o_{j}^{M u(u)}=\sum_{i=1}^{l_{j}} o_{i j}^{u(u)}$; and $o_{i j}^{u(u)}=u v_{i j}^{u} q_{i j}^{u}$, the output value of matched product $i$ in country $u$ at own prices. Using (1), (4) can be rewritten as:

$$
U V R_{j}^{x u(u)}=\frac{\sum_{i=1}^{l_{j}} u v_{i j}^{x} q_{i j}^{u}}{\sum_{i=1}^{l_{j}} u v_{i j}^{u} q_{i j}^{u}}
$$

with $U V R_{j}^{x u(u}$, indicating the Laspeyres index which is the unit value ratio between country $u$ and $x$ weighted at base-country quantities indicated by the $u$ between brackets. For the Paasche index, weights of the other country quantities valued at base country prices are used in formula (3). This gives:

$U V R_{j}^{x u(x)}=\sum_{i=1}^{I_{j}} w_{i j}^{u(x)} U V R i j$

with $w_{i j}^{u(x)}=o_{i j}^{u(x)} / o_{j}^{M u(x)} ; o_{j}^{M u(x)}=\sum_{i=1}^{l_{j}} o_{i j}^{u(x)}$; and $o_{i j}^{u(x)}=u v_{i j}^{u} q_{i j}^{x}$, the output value of matched product $i$ in country $x$ at $u$ prices... Using (1), (6) can be rewritten as:

$U V R_{j}^{x u(x)}=\frac{\sum_{i=1}^{l_{j}} u v_{i j}^{x} q_{i j}^{x}}{\sum_{i=1}^{l_{j}} u v_{i j}^{u} q_{i j}^{x}}$

with $U V R_{j}^{x u(x)}$ indicating the Paasche index which is the unit value ratio between country $u$ and $x$ weighted at the quantities of the other country $(x)$.

\section{Aggregation Step Two: Branch Level UVRs}

Branch UVRs $\left(U V R_{k}\right)$ are calculated as a weighted average of industry UVRs. Use of weights from the base country and the industry UVRs at base country weights, gives the Laspeyres index for branch $k$.

$U V R_{k}^{x u(u)}=\sum_{j=1}^{J_{k}} w_{j k}^{u(u)} U V R_{j k}^{x u(u)}$

with $j=1, \ldots, J_{k}$ representing the number of industries in branch $\mathrm{k}$ in which a product match has been made and $w_{j k}^{u(u)}$ being the industry weight. UVRs of industries with bigger output should have a higher weight to reflect the structure of the economy.

To arrive at the Paasche index, the output weights of country $x$ valued at base prices is substituted. This gives: 
$U V R_{k}^{x u(x)}=\sum_{j=1}^{J_{k}} w_{j k}^{u(x)} U V R_{j k}^{x u(x)}$

\section{Aggregation Step Three: Total Manufacturing UVRs}

The total manufacturing UVR is a weighted average of the branch UVRs. Use of weights from the base country and the branch UVRs at base country weights, gives the Laspeyres index for total manufacturing $\left(U \vee R^{x u(u)}\right)$.

$U V R^{x u(u)}=\sum_{k=1}^{K} w_{k}^{u(u)} U V R_{k}^{x u(u)}$

with $k=1, \ldots, k$ representing the number of branches and $w_{k}^{u(u)}$ representing the branch weight. For branch weights the total branch output is used.

To arrive at the Paasche index, the output weights of country $x$ valued at base prices is substituted. This gives:

$U V R^{x u(x)}=\sum_{k=1}^{K} w_{k}^{u(x)} U V R_{k}^{x u(x)}$

Originally ICOP was based on ISIC rev 2, though some aggregated branches (3 digits) were taken such as basic and fabricated metals (which are separate branches in ISIC rev 2). Since then the industrial classifications have changed across the world. ISIC was revised in 1990 to rev 3. ICOP at the moment distinguishes 14 to 16 (depending on whether food is taken together with beverages and tobacco) branches in manufacturing (our previous comparison followed this classification). In the current comparison we adopted the proposed new ICOP branches including 17 branches as suggested in Timmer et al. (2001).

\section{Appendix 2 \\ The Approach to Construct a Chinese Unit Value List \\ In order to construct a commodity list of Chinese products with their corresponding quantities, output values and unit values for purposes of international comparisons, we have the following data sources:}

\section{A long list of QuAntities from the Chinese 1995 Industrial Census (P. 234)}

The table heading is: "output of major industrial products of industrial enterprises and subsidiary units dealing with industrial production". We know that in principle the coverage of this list is intended to be for the total economy. However, based on the examination of data from the various sources, it is possible that output of the small private enterprises and sole proprietorships is not well covered. On the other hand, the subsidiaries (non independent accounting enterprises) are explicitly included. 
The problem is that this list is not complete. The National Bureau of Statistics of China has a longer list of quantities, which has not been published because of doubts about the quality of the data. This means that using the quantities as weights may involve bias. Sometimes the quantities listed seem to be very modest for a large country such as China. The possible incompleteness of the quantity list is a potential source of bias in the weighting of the unit values from the matches.

\section{AVERAge PRICES FOR LARGE \& MEDIUM ENTERPRISES BY QUALITY FROM THe Chinese 1995 Industrial Census (P. 314)}

The table heading is: product quality of national large-size and medium-size independent accounting enterprises. Since IAS enterprises are generally limited to township and above levels, most probably the coverage of this data is identical to page 46 of the Chinese 1995 Industrial Census (independent accounting enterprises at the township level and above), but within that category it is limited to large and medium enterprises. That category of large and medium enterprises accounts for 56 per cent of gross output and 62 per cent of value added. This source provides total quantities and total values, so that one can calculate unit values for 450 items. It also provides quantities and values of first, second and third quality products.

The average prices can be used directly in product matches. The unit values can be weighted by the quantities in the list. Once the unit values by sample industry have been derived, they can be applied at the township level and above. The branch unit values calculated at the township level and above can also be applied to higher levels of coverage.

\section{Average prices and sales revenues from Chinese 1995 Industrial Census (P. 382)}

The table heading is: "sales income and sales expenditure of national large-size and medium-size independent accounting enterprises". This table lists some 450 average prices and sales revenues for large-size and medium-size independent accounting enterprises. The coverage of this list is identical to previous sources. This table contains information about average prices, sales revenue and sales cost. We may safely assume the average prices refer to sales prices. Dividing sales revenue by average prices would result in an implicit sales quantity list, which could well be used as weights for the calculation of UVRs for the township level and above.

\section{EX FACTORY PRICES FROM A GOVERNMENT AGENCY WEBSITE}

This is a data set of firm level ex factory prices from a government agency price website, starting from 1998. We have used the price index to put the price back to the 1995 benchmark. Because at present the data on detailed price indexes are not satisfactory, this price backward procedure is a very rough approximation.

For the current study, we reconciled the values, quantities and prices information from the different sources to compile a 1995 Chinese commodity listing. This list provided a unit value list for a large number of commodities. The coverage of the unit value list is identical to the coverage of the large and medium enterprises for the township level and above. 
When we have the output values and average prices data, we can divide output values by average prices from large and medium coverage, to derive the quantities information. This procedure is definitely preferable to the procedure adopted in the 1985 China and US comparison. The rationale behind the approach is that average prices from large and medium coverage are applicable to the whole economy, which is a reasonable assumption often used in ICOP studies. This procedure avoids one of the important drawbacks of early procedure, namely that the coverage of the quantities and the values may not correspond.

Table A2.1 Coverage ratio: gross value of matched as $\%$ of total gross value of output in sample industries, China and Germany, 1995

\begin{tabular}{lrrr}
\hline \multicolumn{1}{c}{$\begin{array}{c}\text { Branch and Sample Industries } \\
\text { within the Branch }\end{array}$} & $\begin{array}{c}\text { China, } \\
1995\end{array}$ & $\begin{array}{c}\text { Germany, } \\
1995\end{array}$ & $\begin{array}{c}\text { Number of } \\
\text { Matches }\end{array}$ \\
\hline 1. Food and Kindred Products & 33.83 & 20.51 & 18 \\
1. Forage and Grain Mill Products & 18.65 & 37.67 & $\mathbf{3}$ \\
2. Edible Vegetable Oil & 11.62 & 18.54 & $\mathbf{3}$ \\
3. Salt Industry & 31.73 & 84.91 & $\mathbf{1}$ \\
4. Sugar \& Sugar Factories & 47.97 & 68.16 & $\mathbf{1}$ \\
5. Food Products & 9.87 & 4.50 & $\mathbf{2}$ \\
6. Milk & 22.23 & 6.35 & $\mathbf{1}$ \\
7. Beverages & 41.32 & 58.34 & $\mathbf{6}$ \\
8. Tobacco & 93.03 & 23.56 & $\mathbf{1}$ \\
2. Textiles Mill Products & 39.81 & 42.38 & 23 \\
9. Fibre Raw and Processed Industry & 31.70 & 0.82 & $\mathbf{1}$ \\
10. Textile, Printing and Dyeing Product & 41.05 & 40.66 & $\mathbf{1 9}$ \\
11. Knitting Industry & 34.61 & 90.25 & $\mathbf{3}$ \\
3. Wearing Apparel & $\mathbf{1 0 . 1 2}$ & $\mathbf{1 9 . 5 8}$ & $\mathbf{4}$ \\
12. Wearing Apparel & 11.54 & 21.03 & $\mathbf{4}$ \\
4. Leather Products and Footwear & $\mathbf{1 3 . 7 6}$ & $\mathbf{3 6 . 3 6}$ & $\mathbf{5}$ \\
13. Currying Leather & 33.55 & 61.17 & $\mathbf{2}$ \\
14. Leather Industry & 12.19 & 33.14 & $\mathbf{3}$ \\
5. Wood Products & $\mathbf{1 4 . 8 6}$ & $\mathbf{3 4 . 7 2}$ & $\mathbf{4}$ \\
15. Wood Products & 11.54 & 81.86 & $\mathbf{1}$ \\
16. Man Building Board Proceeding & 29.82 & 81.93 & $\mathbf{3}$ \\
6. Paper Products, Printing \& Publishing & $\mathbf{4 3 . 5 4}$ & $\mathbf{1 1 . 5 4}$ & $\mathbf{6}$ \\
17. Paper Products, Printing \& Publishing & 79.40 & 62.60 & $\mathbf{6}$ \\
7. Chemicals \& Allied Products & 15.79 & 8.00 & $\mathbf{3 0}$ \\
18. Inorganic Chemicals & 80.66 & 9.33 & $\mathbf{5}$ \\
19. Fertilizer & 11.34 & 44.19 & $\mathbf{3}$ \\
20. Pesticides & 2.02 & 59.92 & $\mathbf{2}$ \\
21. Organic Chemicals & 23.63 & 5.47 & $\mathbf{1 1}$ \\
22. Chemical Fibers & 5.67 & 4.55 & $\mathbf{1}$ \\
23. Special Purpose Chemical Products & 27.03 & 26.63 & $\mathbf{3}$ \\
24. Daily Chemical Products & $\mathbf{6 3 . 4 2}$ & $\mathbf{1 3 . 8 0}$ & $\mathbf{1 3}$ \\
8. Petroleum \& Coal Products & 63.42 & 13.80 & $\mathbf{1 3}$ \\
25. Petroleum Refineries & & &
\end{tabular}


9. Rubber and Plastic Products

68.05

39.39

37.45

22.01

27. Plastics

84.86

45.37

13

0. Non-Metallic Mineral Products

18.49

13.90

16.95

16.65

28. Cements

29. Glass and Glass Fibres products

66.87

30. Concrete Products and Fibrotile

4.37

25.82

31. Waterproof, Heat Preservation

32. and Asbestos Products

30.20

4.42

3

33. Other Enduring Fire Materials

77.63

34.50

78.95

71.76

36.31

170.61

0.05

58.26

10

34. Iron and Steel

35. Non-ferrous Metals

47.68

17.05

6.15

17.05

19

6.15

17.17

18.35

7.42

49.12
21.96

40.97

38. Metal Proceeding Industry

10.92

39. Common Machine Industry

6.61

6.32

15.74

41. Agriculture and Forest Machine Industry

54.80

76.52

32.71

39.17

66.30

66.36

42. Railway Industry

43. Road Transport Equipment

44. Ships

42.23

47.46

40.72

43.65

2

7

3

15. Office, Accounting and Computing Machinery

20.91

45. Office, Accounting and Computing Machinery

20.91

33.68

33.68

5

2

16. Electrical Machinery and Equipment

23.92

14.81

10.01

46. Electrical Machinery and Equipment Industry

13.78

20.28

47.95

48. Electrical Household Appliances

52.06

28.20

49. Electronics and Telecommunication

59.43

13.22

50. Communication Equipment

35.36

39.77

51. Measurement Instruments

11.77

9.94

24

12

12

17. Other Manufacturing Products

52. Other Manufacturing Products

3.17

1.99

3.17

1.99

32.80

21.49

6

6

70

9

26

11

15

9

Total Manufacturing:

\section{6.}

Sources: Value: IAS enterprises at the township level and above, p. 46

Price: I and $m$ enterprises at the township level and above, p. 46. 


\section{REFERENCES}

Ark, B., van, 1993a. The ICOP approach - its implications and applicability, in Szirmai, A., Pilat, D., van Ark, B. (Eds), Explaining Economic Growth. Essays in Honour of Angus Maddison, Elsevier, North Holland, 375-398.

Ark, B. van, 1993b. International comparisons of output and productivity - Manufacturing productivity performance of ten countries from 1950 to 1990, Monograph Series, No.1, Groningen Growth and Development Centre, Groningen.

Ark, B. van, Pilat, D., 1993. Productivity Levels in Germany, Japan and the United States: Differences and Causes, Brookings Papers on Economic Activity, Microeconomics 2, Washington D.C.

Fouquin, M., Lemoine, F. (Eds), 1998. The Chinese Economy, Paris, Economica.

Maddison, A., 1998. The Chinese economy in the long run, OECD Development Centre, Paris.

Maddison, A., van Ark, B., 1988. Comparisons of real output in manufacturing, World Bank, Working Paper WP5.

Ren, R., 1997. China's economic performance in an international perspective, OECD Development Centre, Paris.

Ren, R., Szirmai, A., Bai, M., 2002. A new benchmark comparison in manufacturing between China and the US by ICOP approach, School of Economics and Management, Beijing University of Aeronautics and Astronautics, mimeo.

Szirmai, A., Ren, R., 1995. China's manufacturing performance in comparative perspective, 19801992, Research Memorandum 581 (GD-20), Groningen Growth and Development Centre, Groningen.

Szirmai, A., Ren, R., 1998. Chinese manufacturing in comparative perspective', in Fouquin, M., Lemoine, F. (Eds), (1998), 49-64.

Szirmai, A., Ren, R., 2000. Comparative performance in Chinese manufacturing, 1980-92, China Economic Review 11(1), 16-53.

Szirmai, A., Bai, M., Ren, R., 2001. Labour Productivity Trends in Chinese Manufacturing, 19801999, working paper 01.10, Eindhoven Centre for Innovation Studies (www.tm.tue.nl/ecis).

Ren, R., Szirmai, A., Bai, M., 2002. How productive is Chinese manufacturing? Comparative labour productivity in Chinese manufacturing, 1980-1999, paper presented at the 27th general conference of The International Association for Research in Income and Wealth, Stockholm, August 18-24.

Timmer, M., van Ark, B., Mulder, N., Nayman, L., Ünal-Kesenci, D., 2001. Formalization of the ICOP methodology for binary manufacturing comparisons, unpublished draft. 


\section{Statistical Sources}

\section{For China:}

Census 1985. National Bureau of Statistics, (1987-88), Office of Leading Group of the National Industrial Census under the State Council, Peoples Republic of China, Industrial Census 1985, Vol. I$X$, Beijing: China Statistics Press.

Census 1995. National Bureau of Statistics, Office of the Third Industrial Census (1997), Vol: The Data of the Third National Industrial Census of the People's Republic of China in 1995, Beijing: China Statistics Press.

Industry and Transport, 1949-1999, 2000. Beijing: China Statistics Press, November.

National Bureau of Statistics, 1996. 1996 Chinese Industrial Economy Statistics Yearbook, Beijing: China Statistics Press.

National Bureau of Statistics, 1996. 1996 China Statistical Yearbook, Beijing: China Statistics Press.

National Bureau of Statistics, Department of Industry and Transport. Statistics of China's, Beijing: China Statistics Press.

National Bureau of Statistics, Department of National Accounts, 1997. Input-Output Table of China, 1995, Beijing: China Statistics Press.

National Bureau of Statistics, Department of Population, Social Science and Technology Statistics, 1996. 1996 China Labour Statistical Yearbook, Beijing: China Statistics Press.

\section{For Germany:}

Statistisches Bundesamt, 1995. Produzierendes Gewerbe. Fachserie 4. Reihe 4.3. Kostenstruktur des Unternehmen im Verarbeitenden Gewerbe sowie im Bergbau und der Gewinnung von Steihen und Erden.

Statistisches Bundesamt, 1995. Produktion im produzierenden Gewerbe des In-und Auslands. 